\title{
Structural, Antioxidant and Antivarial Studies of $C$-3-nitrophenyl CALIX[4]resorcinarene
}

\author{
Bohari M Yamin", Hamza M Abosadiya *, Siti Aisah Hasbullah and Jumina ${ }^{\#}$ \\ \# School of Chemical Sciences, Universiti Kebangsaan Malaysia, Bangi, 43600, Selangor Malaysia \\ E-mail: bohari@ukm.edu.my \\ ${ }^{\#}$ Department of Chemistry, Faculty of Mathematics and Natural Sciences, Gadjah Mada University, Indonesia \\ E-mail:pak_jumina@yahoo.com
}

\begin{abstract}
The calix[4]arene derivative $C$-3-nitrophenylcalix[4]resorcinarene was synthesized by using one-pot reaction of resorcinol with 3-nitrobenzaldehyde in the presence of concentrated $\mathbf{H C l}$. The compound was characterized by IR, ${ }^{1} \mathrm{H}$ and ${ }^{13} \mathrm{C}$ NMR spectroscopy. X-ray crystallographic study showed that this compound crystallized in a triclinic system with space group of $P \overline{1}$ and the unit cell dimensions, $a=10.6143(3) \AA, b=13.6262(4) \AA, c=14.7971(5) \AA, \alpha=102.813(3)^{\circ}$, $\beta=110.917(3)^{\circ}, \gamma=90.885(2)^{\circ} . V=1938.78(11) \AA^{3}$ and $Z=2$. The biological Studies were also investigated. It has a stromg antioxidant property and high antiviral activity against HSV-1 . Cytotoxicity testing on Vero cells showed that it is non-toxic, with a $\mathrm{CC}_{50}$ of more than $0.4 \mathrm{mg} / \mathrm{mL}$. Moderate antibacterial activity.
\end{abstract}

Keywords-C-3-nitrophenylcalix[4]resorcinarene, X-ray structural study and Biological Studies.

\section{INTRODUCTION}

Calixarene which was discovered by Adolf Von Baeyer in 1872 can now be considered as technology materials. The supramolecular future with cavitand that can display hostguest activity made the calixarene a good candidate as absorbant and material for sensor devices [1-5]. Therefore, it is not surprising that the development in these two areas of application has been quite rapid. In order to improve the performance of a device a new design of the active agent based on rational design and modelling is carried out before attempting the synthesis work. The synthesis work has always been the key step to a successful and continuing development in the product devdelopment. Calixarene is basically a phenolic macrocycle. Therefore it should display antioxidant property. The biological application of calixarene derivatives has currently become an interest to many researchers world-wide [6]. One major problem for the application in certain field is its low solubility and flexible existence of their conformers [7-10]. The presence of more than one conformer in the solution can be determined by NMR studies. However, in the solid state the CALIX[4]resorcinarene faced stability problem after crystallization. Therefore there are relatively less structures of the calix have been reported compare to their calix with aliphatic linkers. In this paper the structural study of C-3nitrophenylcalix [4]resorcinarene by X-ray crystallography and biological study including antiviral activity are presented.

\section{EXPERIMENTAL}

All the compounds utilized in this work were commercially available with high purity purchased from Acros Organics (Geel, Belgium) and Sigma-Aldrich (St Louis, MO, USA) and were used without further purification. All solvents were distilled before use. The microelemental analysis for CHNSO was carried out using a Carlo Erba 1108 Elemental Analyzer (Milan, Italy). The infrared spectrum (IR) of the product ( $\mathrm{KBr}$ pellets) was recorded using a Perkin Elmer Spectrum GX spectrophotometer (Perkin Elmer, Waltham, MA, USA) in the range of 400-4,000 $\mathrm{cm}^{-1}$. Nuclear Magnetic Resonance $\left({ }^{1} \mathrm{H}\right.$ and $\left.{ }^{13} \mathrm{C}\right)$ experiments were performed on a Bruker $600 \mathrm{MHz}$ instrument using DMSO- $\mathrm{d}_{6}$ as the solvent. Single-crystal X-ray experiment was performed on Bruker D-QUEST diffractometer (Bruker, AXS Inc., Madison, WI, USA) using graphitemonochromated Mo-K $\alpha$ radiation $(\lambda=0.71073 \AA$ ). 


\section{A. Preparation of C-3-nitrophenylcalix[4]resorcinarene}

Concentrated hydrochloric acid $(7 \mathrm{~mL})$ was added into a round-bottom flask containing a solution of 3nitrobenzaldehyde $(0.01 \mathrm{~mol}, 1.51 \mathrm{~g})$ in absolute ethanol $(60$ $\mathrm{mL})$. The mixture was stirred for 30 minutes and a solution of resorcinol $(0.01 \mathrm{~mol}, 1.10 \mathrm{~g})$ in absolute ethanol $(20 \mathrm{~mL})$ was added. The mixture was refluxed for 24 hours at $80{ }^{\circ} \mathrm{C}$. The yellow precipitate formed was collected by filtration, washed with distilled water and acetone several times and dried under vacuum. Yield (82\%); FTIR $\left(\mathrm{KBr}, \mathrm{cm}^{-1}\right): 3399$ $(\mathrm{OH}), 1516(\mathrm{C}=\mathrm{C}), 1313(\mathrm{C}-\mathrm{N}) ; 1204(\mathrm{C}-\mathrm{O}),{ }^{1} \mathrm{H}-\mathrm{NMR}(600 \mathrm{~Hz}$; precipitate, DMSO-d $\left.{ }_{6}\right) \delta_{\mathrm{H}}: 4.91(2 \mathrm{H}, \mathrm{s}, \mathrm{Ar}-\mathrm{CH}), 5.23(2 \mathrm{H}, \mathrm{s}$, Ar- $\mathrm{CH}), 6.21$ (4H, s, Ar-CH), 6.02 (4H, s, Ar-CH), 7.12 $(4 \mathrm{H}, \mathrm{t}, \mathrm{Ar}-\mathrm{CH}), 7.36$ (4H, S, Ar- $\mathrm{CH}), 7.69$ (4H, d, Ar-CH), $7.76(4 \mathrm{H}, \mathrm{d}, \mathrm{Ar}-\mathrm{CH}), 8.92(4 \mathrm{H}, \mathrm{s}, \mathrm{OH}), 9.0(4 \mathrm{H}, \mathrm{s}, \mathrm{OH}) ;{ }^{13} \mathrm{C}-$ NMR $(150 \mathrm{MHz}$; DMSO-d 6$) \delta_{\mathrm{C}}: 41.9(4 \times \mathrm{CH}), 102.4(4 \times$ Ar-H $), 119.6(4 \times$ Ar-CH $), 120.5(4 \times$ Ar-CH $), 120.5(2 \times$ Ar-CH $), \quad 128.6(2 \times$ Ar-CH $), 129.8(2 \times$ Ar-H $), 133.8(4 \times$ Ar-H $), 135.2(4 \times$ Ar-H $), 147.3(4 \times$ Ar-CH $), 153.4(4 \times$ Ar$\mathrm{OH}), 153.7(4 \times \mathrm{Ar}-\mathrm{OH}), 153.9\left(4 \times \mathrm{Ar}-\mathrm{NO}_{3}\right)$. Analysis Calcd (\%): $\mathrm{C}=60.24$ and $\mathrm{H}=3.50$ and $\mathrm{N}=5.40$. Found $(\%): \mathrm{C}=$ 60.12 and $\mathrm{H}=3.30$ and $\mathrm{N}=5.20$.

\section{B. Cytotoxicity Evaluation}

The cytotoxicity of the compound was first determined on uninfected Vero cells (African monkey Cercophiteus aetiops kidney cells) with dilutions ranging from $5 \mathrm{mg} / \mathrm{mL}$ to 0.039 $\mathrm{mg} / \mathrm{mL}$ in Dulbecco's Modified Eagle's Medium (DMEM, Flowlab, North Ride, Australia). Cytotoxicity was determined using the MTT assay [11]. The $\mathrm{CC}_{50}$ value that is the compound concentration that kills $50 \%$ of the cell population was determined by the optical density of solubilized formazan. The percentage of growth inhibition was calculated using the following formula:

$$
\% \text { Cell viability }=100 \times(\mathrm{Abs} / \mathrm{Ac}),
$$

where $\mathrm{Abs}=$ Absorbance value of test compound and $\mathrm{Ac}=$ Absorbance value of control (cells only).

\section{Antiviral Activity}

The plaque reduction assay was performed to study the presence of antiviral activity of compound. HSV-1 stock was prepared and the viral titre of the stock was determined as $5.7 \times 108 \mathrm{pfu} / \mathrm{mL}$. The concentration of compound used in this assay was set based on the concentration that allows growth of $70 \%$ or more Vero cells. This is to ensure that cell death is not due to the toxicity of the test compound which will affect the accuracy of the test results. In this study, the first test concentration of (I) is $0.35 \mathrm{mg} / \mathrm{mL}$, which is below the CC50 value and continues with two fold serial dilutions until $0.011 \mathrm{mg} / \mathrm{mL}$. Virus was infected to $80 \%$ confluent cells and incubated for 48 hours for plaque formation. Plaques were stained with crystal violet and the numbers of plaques were counted. The EC50 value was determined as the concentration that inhibited plaque formation by $50 \%$ of the untreated cells [12].

\section{Antioxidant Test}

A stock solution of DPPH was prepared by dissolving DPPH $(0.4 \mathrm{~g})$ in methanol $(1 \mathrm{~L})$ and the solution was kept in the dark at $4^{\circ} \mathrm{C}$. A stock solution of the 3-ntrophenylcalix [4]resorcinarene was prepared at $10 \mathrm{mg} / 5 \mathrm{~mL}$ in DMSO. A volume of $100 \mu \mathrm{L}$ from the stock solution of the compound was added to $1 \mathrm{~mL}$ of DPPH. The mixture was shaken well and kept in the dark at room temperature for 2 hours. The absorbance of the mixture was measured at $517 \mathrm{~nm}$ using a spectrophotometer. The percentage of inhibition of radical scavenging ability was calculated as:

Inhibition \% $=\left[\left(\mathrm{A}_{\mathrm{DPPH}}-\mathrm{A}_{\text {Sample }}\right) /\left(\mathrm{A}_{\mathrm{DPPH}}\right)\right] \times=[(1.012-$ $0.176) / 1.012] \times 100=82.60 \%$.

\section{RESULTS AND DISCUSSION}

\section{A. Synthesis and Characterization}

The synthesis of C-3-nitrophenylcalix[4]resorcinarene was accomplished by refluxing mixture of equal molar amounts of resorcinol with 3-nitrobenzaldehyde in the presence of concentrated $\mathrm{HCl}$ in $\mathrm{EtOH}$ at $80^{\circ} \mathrm{C}$. The FTIR spectrum of the compound showed characteristics absorption at $3399 \mathrm{~cm}^{-1}$ corresponds to $\mathrm{O}-\mathrm{H}$ stretching vibration. The $(\mathrm{C}=\mathrm{C})$ and $v(\mathrm{C}-\mathrm{N})$ stretching frequencies appeared at 1516 and 1313 $\mathrm{cm}^{-1}$, respectively. ${ }^{1} \mathrm{H}-\mathrm{NMR}$ spectrum of compound showed the resorcinol protons appeared at 8.92 and $9.0 \mathrm{ppm}$, respectively. The different conformations of calix[4] resocinarene can also be observed from the different chemical shift of methine linkage protons (4.91 and 5.23 ppm) indicated that the calix[4]arenes molecule adopts a chair conformation. The ${ }^{13} \mathrm{C}-\mathrm{NMR}$ spectrum showed the carbon chemical shifts of the two sets of the phenolic carbon at 153.4 and $153.7 \mathrm{ppm}$. The four tertiary methine carbons appeared at $41.9 \mathrm{ppm}$. The aromatic carbon chemical shifts appeared in the range of 102.4-153.9 ppm.

\section{B. X-Ray Structure}

X-ray investigation showed that the compound crystallized in triclinic system with space group of Pĩ. The unit cell dimension are $\mathrm{a}=10.6143(3) \AA, \mathrm{b}=13.6262(4) \AA$, $\mathrm{c}=14.7971(5) \AA, \alpha=102.813(3)^{\circ}, \beta=110.917(3)^{\circ}, \gamma=$ $90.885(2)^{\circ} . \quad V=1938.78(11) \AA^{3}$ and $\mathrm{Z}=2$. The crystal system and refinement parameters are given in Table 1 .

TABLE 1

CRYSTALLOGRAPHIC DATA AND STRUCTURAL REFINEMENT OF C-3NITROPHENYLCALIX[4]RESORCINARENE

\begin{tabular}{|l|l|}
\hline Crystal parameters & Data/values \\
\hline Empirical formula & $\mathrm{C}_{60} \mathrm{H}_{62} \mathrm{~N}_{4} \mathrm{O}_{25} \mathrm{~S}_{4}$ \\
\hline Temperature & $293(2) \mathrm{K}$ \\
\hline Wavelength & $1.54178 \AA$ \\
\hline Crystal system & Triclinic \\
\hline Space group & $\mathrm{P} \tilde{1}$ \\
\hline Unit cell dimensions & $\mathrm{a}=10.6143(3) \AA$ \\
& $\mathrm{b}=13.6262(4) \AA$ \\
& $\mathrm{c}=14.7971(5) \AA$ \\
& $\alpha=102.813(3)^{\circ}$. \\
& $\beta=110.917(3)^{\circ}$. \\
& $\gamma=90.885(2)^{\circ}$. \\
\hline Volume & $1938.78(11) \AA^{3}$ \\
\hline Z & 2 \\
\hline Density (calculated) & $1.399 \mathrm{Mg}^{3} \mathrm{~m}^{3}$ \\
\hline Absorption coefficient & $2.812 \mathrm{~mm}^{-1}$ \\
\hline
\end{tabular}




\begin{tabular}{|l|l|}
\hline $\mathrm{F}(000)$ & 860 \\
\hline Crystal size & $0.40 \times 0.32 \times 0.26$ \\
\hline $\begin{array}{l}\text { Theta range for data } \\
\text { collection }\end{array}$ & 3.296 to $71.486^{\circ}$. \\
\hline Index ranges & $\begin{array}{l}-13<=\mathrm{h}<=13,-16<=\mathrm{k}<=16,- \\
12<=1<=11\end{array}$ \\
\hline Reflections collected & 21497 \\
\hline Independent reflections & $3773[\mathrm{R}(\mathrm{int})=0.0208]$ \\
\hline $\begin{array}{l}\text { Completeness to theta }= \\
67.679^{\circ}\end{array}$ & $51.5 \%$ \\
\hline Refinement method & matrix least-squares on $\mathrm{F}^{2}$ \\
\hline $\begin{array}{l}\text { Data / restraints } \\
\text { parameters }\end{array}$ & $3773 / 0 / 498$ \\
\hline Goodness-of-fit on $\mathrm{F}^{2}$ & 1.045 \\
\hline $\begin{array}{l}\text { Final R indices } \\
{[\mathrm{I}>2 \text { sigma(I)] }}\end{array}$ & $\mathrm{R} 1=0.0644, \mathrm{wR} 2=0.1570$ \\
\hline $\mathrm{R}$ indices (all data) & $\mathrm{R} 1=0.0668, \mathrm{wR} 2=0.1592$ \\
\hline Extinction coefficient & $\mathrm{n} / \mathrm{a}$ \\
\hline $\begin{array}{l}\text { Largest diff. peak and } \\
\text { hole }\end{array}$ & 1.179 and -1.200 e. $\AA^{-3}$ \\
\hline
\end{tabular}

The calix molecule adopts a chair conformation (C2h) with two opposite resorcinol groups almost coplanar to each other and an other pair that are anti-parallel (Figure 1).

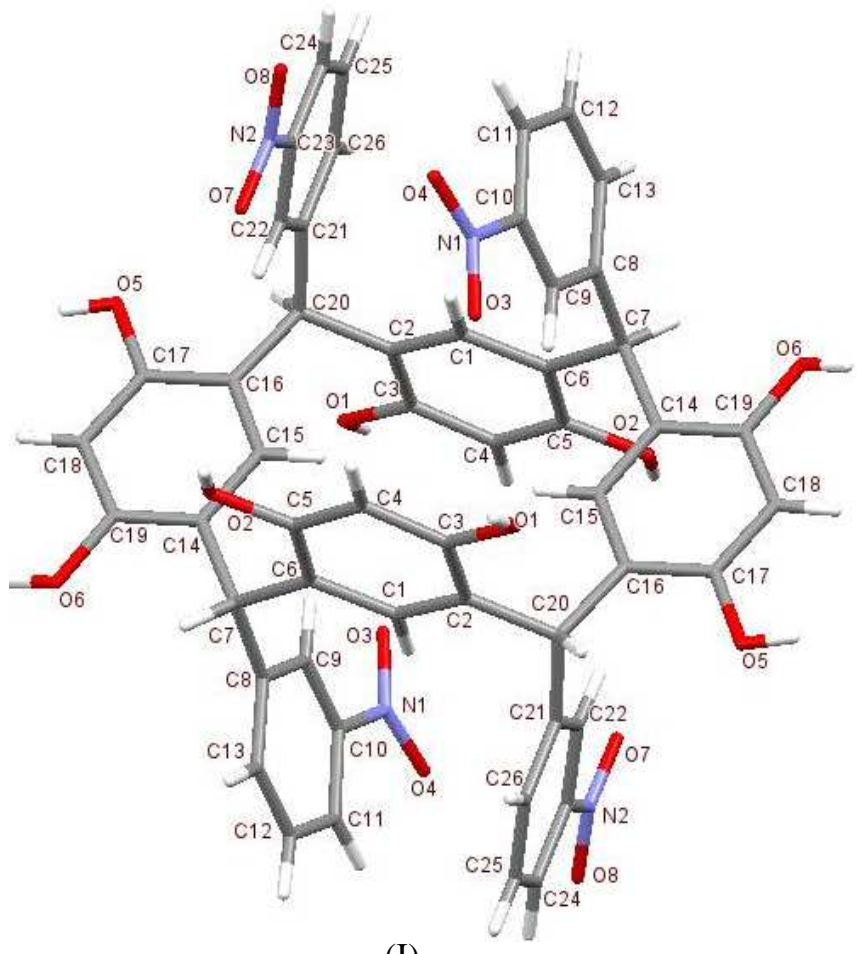

(I)

Figure 1. The molecular structure of $C$-3-nitro phenyl calix[4]resorcinarene(I). The solvent molecules are not shown for clarity.

The alternate resorcinol rings $(\mathrm{C} 1-\mathrm{C} 6)$ and $(\mathrm{C} 14-\mathrm{C} 19)$ are perpendicular with a dihedral angle of $84.1(3)^{\circ}$. The dihedral angle between the resorcinol ring $(\mathrm{C} 1-\mathrm{C} 6)$ and 3nitrophenyl linkage group (C8-C13) is $87.4(3)^{\circ}$, indicate a high degree of co-planarity between the resorcinol rings and lead to the adoption of a chair conformation. A similar conformation with approximately $\mathrm{C}_{2 \mathrm{~h}}$ symmetry due to the presence of a crystallographic inversion center has also been observed for tetraarylboronic acid resorcinarene [10].

\section{Biological Studies}

The cytotoxicity test indicated that $C$-3-nitrophenylcalix[4] resorcinarene is safe to be used as an antimicrobial therapeutic agent due to its non-toxicity against Vero cells with a $\mathrm{CC}_{50}$ value of $5 \mathrm{mg} / \mathrm{mL} \cdot \mathrm{mg} / \mathrm{mL}$. The $\mathrm{CC}_{50}$ was obtained from the graph of percentage of cell survival viability versus compound concentration (Figure 2).

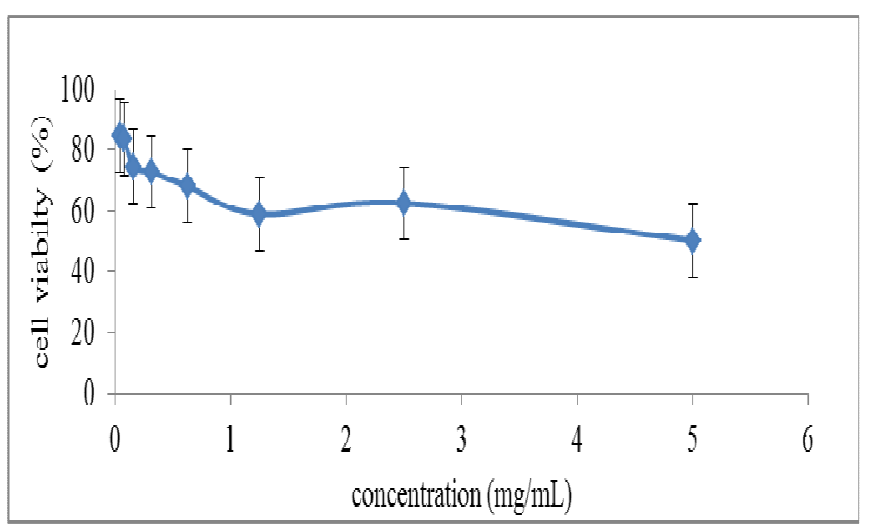

Figure 2. Percentage of cell survival against concentration of compound that $C$-3-nitrophenylcalix[4] resorcinarene

Antiviral tests showed that the compound C-3-nitro phenyl calix[4]resorcinarene is a good candidate as an antiviral agent because of its ability to inhibit $100 \%$ plaque formation, even at the lowest concentration of $0.011 \mathrm{mg} / \mathrm{mL}$. Thus, the $\mathrm{EC}_{50}$, which is the concentration when the presence of test compound caused 50\% reduction of plaques or cytopathic effect, is much lower than the minimum inhibitory concentration of $0.011 \mathrm{mg} / \mathrm{mL}$. The selectivity index $\left(\mathrm{SI}=\mathrm{CC}_{50} / \mathrm{EC}_{50}\right)$ of compound $\mathbf{I}$ is more than 36 . This indicates that compound can be considered as a potentially safe antiviral agent with low cytotoxicity and high potency. SI values greater than 10 indicate potential antiviral therapeutic safety and efficacy.

Antioxidant properties measured as radical scavenging activity are due to the transfer of electrons or hydrogen atoms of the hydroxyl groups to an oxidizing agent. Compound being a polyphenolic compound, could inhibit the oxidation of other molecules such as 1,1-diphenyl-2picryl-hydrazyl (DPPH) by donating hydrogen atoms to form the stable non-radical form of DPPH as shown by the formation of a pale yellow color. The antioxidant activity exhibited by compound was $82.60 \%$.

\section{CONCLUSIONS}

C-3-nitrophenylcalix[4]resorcinarene was successfully synthesized by the cyclocondensation of 3-nitro benzaldehyde and resorcinol in the presence of concentrated $\mathrm{HCl}$. The X-ray structure was in good agreement with the NMR data and the calix molecule adopted a chair $C_{2 \mathrm{~h}}$ conformation. The compound showed good anti-HSV-1 and antioxidant activity at non-cytotoxic concentrations. 


\section{ACKNOWLEDGMENT}

The authors thank the Ministry of Higher ducation of Malaysia and Universiti Kebangsaan Malaysia for the research grant DIP-2012-11 and FRGS/1/2013/ST01/ $\mathrm{UKM} / 03 / 4$. One of us HAMZA would like to thank the Ministry of Higher Education of Libya for the scholarship

\section{REFERENCES}

[1] Zhang, Z.; Luo, Y.; Chen, J.; Dong, S.; Yu, Y.; Ma, Z.; Huang, F. Formation of linear supramolecular polymers that is driven by $\mathrm{C}-$ $\mathrm{H} \cdots \pi$ interactions in solution and in the solid state. Angew. Chem. Int. 2011, 50, 1397-1401.

[2] Han, C.; Ma, F.; Zhang, Z.; Xia, B.; Huang, F. DIBPillar[n]arenes (n $=5,6$ ): Syntheses, X-ray crystal structures, and complexation with nOctyltriethyl ammonium hexafluorophosphate. Org. Lett. 2010, 12, 4360-4363.

[3] Zhang, M.; Xu, D.; Yan, X.; Chen, J.; Dong, S.; Zheng, B.; Huang, F. Self-healing supramolecular gels formed by crown ether based host-Guest interactions. Angew. Chem. Int. 2012, 51, 7011-7015.

[4] Zheng, B.; Wang, F.; Dong, S.; Huang, F. supramolecular polymers constructed by crown ether-based molecular recognition. Chem. Soc. Rev. 2012, 41, 16211636.

[5] Turshatov, A.A.; Melnikova, N.B.; Semchikov, Y.D.; Ryzhkina, I.S.; Pashirova, T.N.; Mobius, D.; Zaitsev, S.Y. Interaction of monolayers of calix[4]resorcinarene derivatives with copper ions in the aqueous subphase. Colloids Surf. A Physicochem. Eng. Aspects. 2004, 240, 101-106.
[6] Abosadiya, H. M., Hasbullah, S. A., Mackeen, M. M., Low, S. C., Ibrahim, N., Koketsu, M., \& Yamin, B. M. .Synthesis, Characterization, X-ray Structure and Biological Activities of C-5Bromo-2-hydroxy phenyl calix [4]-2-methyl resorcinarene. Molecules, 2013, 18, 13369-13384.

[7] Makinen, M.; Jalkanen, J.P.; Vainiotalo, P. Conformational properties and intramolecular hydrogen bonding of tetraethyl resorcinarene: An ab initio study. Tetrahedron. 2002, 58, 8591-8596.

[8] Thondorf, I.; Brenn, J.; Bohme, V. Conformational properties of methylene-bridged resorcarenes. Tetrahedron. 1998, 54, 1282312828

[9] Iwanek, W.; Wzorek, A. Introduction to the chirality of resorcinarenes. Mini Rev. Org. Chem. 2009, 6, 398-411.

[10] Davis, C.J.; Lewis, P.T.; Billodeaux, D.R.; Fronczek, F.R.; Escobedo, J.O.; Strongin, R.M. Solid-state supramolecular structures of resorcinol-arylboronic acid compounds. Org. Lett. 2001, 3, 24432445.

[11] Andrighetti-Frohner, C.R; Antonio, R.; Creczynski-Pasa, T.; Barardi, C.; Simoes, C. Citotoxicity and potential antiviral evaluation of violacein produced by Chromobacterium violaceum. Mem. Inst. Oswaldo Cruz. 2003, 98, 843-848

[12] Macedo, N.R.P.V.; Ribeiro, M.S.; Villaca, R.C.; Ferreira, W.; Pinto, A.M.; Teixeira, V.L.; Cirne-Santos, C.; Paixao, I.C.N.P.; Giongo, V. Caulerpin as a potential antiviral drug against herpes simplex virus type 1. Braz. J. Pharmacogn. 2012, 22, 861-867. 